\title{
Occurrence of Fusarium wilt caused by Fusarium oxysporum on strawberry transplants in Aydın Province in Turkey
}

\author{
H. Dinler ${ }^{1} \cdot$ S. Benlioglu ${ }^{2} \cdot$ K. Benlioglu ${ }^{2}$
}

Received: 10 December 2015 / Accepted: 30 March 2016/Published online: 6 April 2016

(C) Australasian Plant Pathology Society Inc. 2016

\begin{abstract}
Samples of strawberry transplants were randomly collected from 47 growers in Aydin province of Turkey. A total of 26 Fusarium oxysporum isolates were identified by morphological characterization, sequence analysis of factor- 1 alpha gene, and pathogenicity tests on strawberry, cucumber and tomato seedlings. To our knowledge, this is the first report of the presence of $F$. oxysporum in strawberry transplants in Turkey.
\end{abstract}

Keywords Fragaria ananassa · Fusarium wilt · Fusarium oxysporum f. sp. fragariae

Turkey is the fourth largest strawberry producer in the world, with an annual production of 372 thousand tones (FAOSTAT 2015). Recent studies indicated that Macrophomina phaseolina and Fusarium spp. were the major fungal pathogens isolated from the crown of dead or dying strawberry plants in Aydin province where $13 \%$ of Turkey's strawberry production takes place (Benlioglu et al. 2014). During two cropping seasons 2009/10 and 2010/11, samples of strawberry transplants from 47 growers were randomly collected and examined for the presence of Fusarium oxysporum. After observation of longitudinal sections of transplants, fungal isolations were made aseptically on Potato Dextrose Agar (PDA) plates from internal vascular and cortical tissues of the crowns exhibiting a brown-to-orange-brown discoloration.

H. Dinler

havva.dinler@usak.edu.tr

1 Department of Plant Protection, Faculty of Agriculture and Natural Sciences, Usak University, 64200 Usak, Turkey

2 Department of Plant Protection, Faculty of Agriculture, Adnan Menderes University, 09100 Aydın, Turkey
Fusarium-like colonies with light purple mycelia and orange reverse colony colours (Fig. 1) were sub-cultured on carnation leaf agar, and observed for microscopic conidial characteristics after obtaining single-spore cultures (Leslie and Summerell 2006). Twenty-six out of 73 Fusarium oxysporum-like strains exhibiting identical morphological characteristics were selected randomly for further identification tests. Macroconidia were 3 to 5 septate, straight to slightly curved, gently tapered and curved at the apical end (15.7 to $35.4 \times 2.9$ to $4.3 \mu \mathrm{m})$. Microconidia were oval elipsoid, 0-septate and formed abundantly on short monophialides (6.1 to $12.5 \times 2.1$ to $3.6 \mu \mathrm{m}$ ) (Fig. 2). Pathogenicity tests were conducted in a growth chamber on 4-week-old strawberry transplants propagated from runners (cv. Camarosa), 4-week-old tomato (cv. Supermarmande) and cucumber (cv. Çengelköy) plants. Spore suspensions $\left(10^{5}\right.$ conidia per $\mathrm{ml}$ ) for each of 26 isolates were prepared and the roots of 5 plants each were dipped in each spore suspension for $15 \mathrm{~min}$ and each plant was transplanted into plastic pot containing sterilized peat. Plants were maintained at $24 \pm 2{ }^{\circ} \mathrm{C}$ with a daily 16-h photoperiod of fluorescent light. Control plants were soaked in water prior to planting. Within 8 weeks, all inoculated strawberry plants exhibited wilting and decline symptoms (Fig. 3) including root rot and vascular discoloration of the crown. All treated tomato and cucumber plants, including control plants did not show any disease symptoms, and vascular discoloration was not observed when longitudinal or transverse cuts were made on the main stems or crown. The pathogenicity test was conducted twice. The fungus was successfully reisolated from the crown of inoculated strawbery plants and identity confirmed as before. Pathogenic Fusarium oxysporum strains were detected in 33 of 47 growers with an average incidence of $10.03 \%$ and $4.25 \%$ in the cropping seasons $2009 / 10$ and 2010/11, respectively

Morphological identification was confirmed by amplification and sequencing of a portion of the translation elongation 


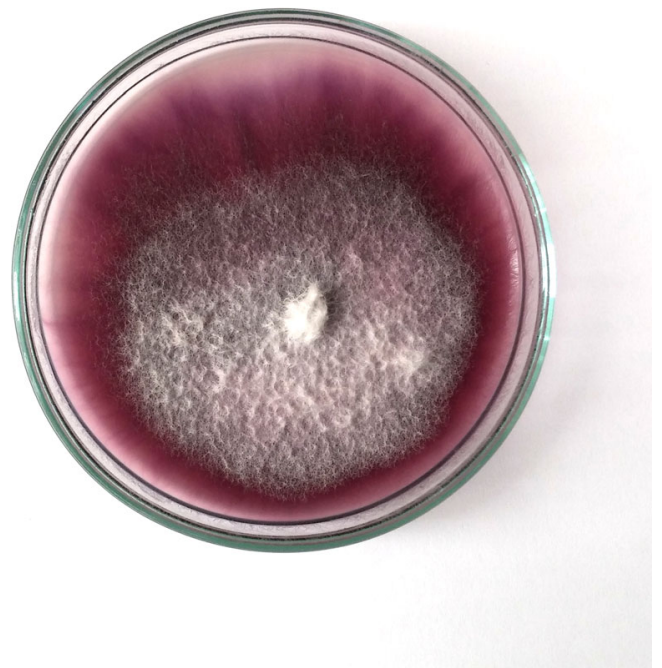

Fig. 1 Fungal growth of Fusarium oxysporum on PDA

factor-1 alpha (TEF-1 $\alpha$ ) gene. Genomic DNA was extracted from 26 pathogenic isolates of Fusarium and amplified using ef1 and ef2 primers (Geiser et al. 2004). Comparative sequence analysis with GeneBank revealed that all 26 isolates showed identity (99 to $100 \%$ ) to the F. oxysporum. Eleven out of 26 F. oxysporum strains also showed $99 \%$ identity to Fusarium oxysporum f.sp. fragariae that is previously reported pathogen of strawberry in many countries in the world (Paynter et al. 2014). Four representative F. oxysporum strains were submitted to GeneBank with accession numbers (KJ776744 to KJ776747). After identification, all of 26 F. oxysporum isolates were deposited in the culture collection of the Plant Protection Department, Agricultural Faculty of Adnan Menderes University, Aydin, Turkey.

Although Fusarium oxysporum in strawberry has been previously reported in Erzurum province of Turkey (Durak and Demirci 2014), to our knowledge this is the first report of the occurrence of $F$. oxysporum $f$. sp. fragariae in strawberry transplants in Turkey. Recent studies indicated that

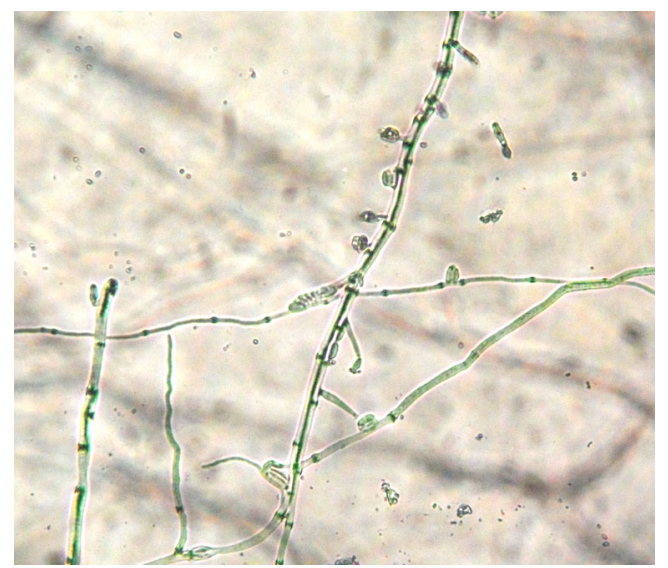

Fig. 2 Microconidia produced in false heads on short monophialides of Fusarium oxysporum under $20 \times$ objective

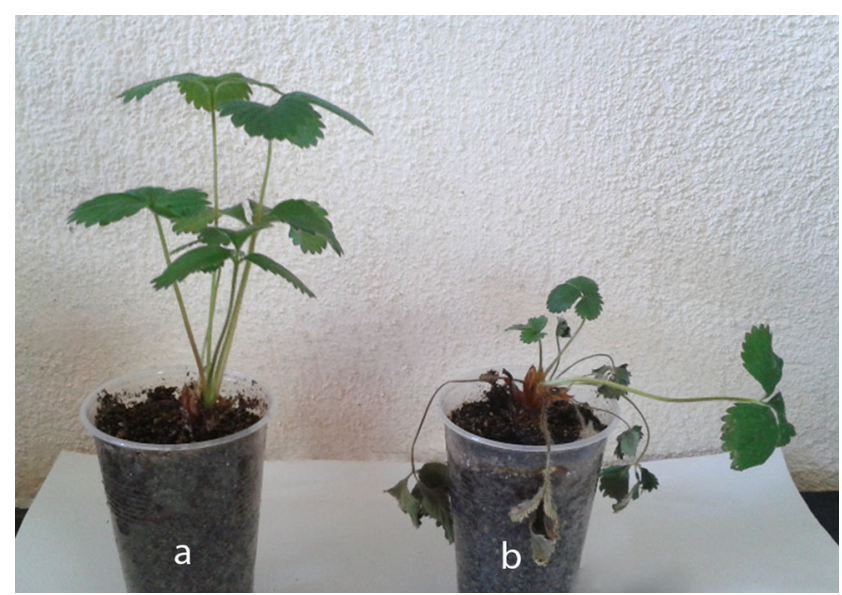

Fig. 3 Pathogenicity test on strawberry plants (cv Camarosa), a Control and $\mathbf{b}$ Inoculated with Fusarium oxysporum $\mathrm{f}$. sp. fragariae

M. phaseolina and Fusarium spp. were the primary reasons leading to death of strawberry plants in Aydin province and soil solarization did not effectively control these soilborne pathogens (Benlioglu et al. 2014). Our results are particularly important because $F$. oxysporum $f$. sp. fragariae has recently been considered as one of the most serious fungal threats to strawberry cultivation in Australia (Golzar et al. 2007; Fang et al. 2012), United States (Koike et al. 2009, 2013), Spain (Arroyo et al. 2009), Korea (Nagarajan et al. 2004) and China (Zhao et al. 2009), and it can also threaten strawberry fruit yield and transplant production in Turkey.

Acknowledgments This study was supported by The Scientific and Technological Research Council of Turkey (TUBITAK) under the project no $110 \mathrm{R} 009$.

\section{References}

Arroyo FT, Llergo Y, Aguado A, Romero F (2009) First report of Fusarium Wilt caused by Fusarium oxysporum on strawberry in Spain. Plant Dis 93:323

Benlioglu S, Yildiz A, Boz Ö, Benlioglu K (2014) Soil disinfestation options in Aydin province, Turkey, strawberry cultivation. Phytoparasitica 42:397-403

Durak ED, Demirci E (2014) Pathogenicity of Fusarium species isolated from strawberry plants in Erzurum province. Bitki Koruma Bülteni 54(3):247-253 (In Turkish)

Fang X, Kuo J, You MP, Finnegan PM, Barbetti MJ (2012) Comparative root colonisation of strawberry cultivars Camarosa and Festival by Fusarium oxysporum f. sp. fragariae. Plant Soil 358:75-89

FAOSTAT (2015) Food and Agriculture Organization (FAO) [Available at http://faostat.fao.org]

Geiser DM, del Mar J-GM, Kang S, Makalowska I, Veeraraghavan N, Ward TJ, Zhang N, Kuldau GA, O'Donnell K (2004) Fusarium-ID v. 1.0: a DNA sequence database for identifying Fusarium. Eur J Plant Pathol 110:473-479

Golzar H, Phillips D, Mack S (2007) Occurrence of strawberry root and crown rot in Western Australia. Aust Plant Dis Notes 2:145-147

Koike ST, Kirkpatrick SC, Gordon TR (2009) Fusarium Wilt of Strawberry Caused by Fusarium and Macrophomina in California. Plant Dis 93:1077 
Koike ST, Gordon TR, Daugovish O, Ajwa H, Bolda M, Subbarao K (2013) Recent Developments on Strawberry Plant Collapse Problems in California Caused by Fusarium and Macrophomina. Int J Fruit Sci 13:76-83

Leslie JF, Summerell BA (2006) The Fusarium Laboratory Manual. Blackwell Publishing, Ames, IA, U.S.A

Nagarajan G, Nam MH, Song JY, Yoo SJ, Kim HG (2004) Genetic variation in Fusarium oxysporum f. sp. fragariae populations based on RAPD and rDNA RFLP analyses. Plant Pathol. J 20:264-270
Paynter ML, De Faveri J, Herrington ME (2014) Resistance to Fusarium oxysporum $\mathrm{f}$. sp. fragariae and predicted breeding values in strawberry. J Amer Soc Hort Sci 139:178-184

Zhao X, Zhen W, Qi Y, Liu X, Yin B (2009) Coordinated effects of root autotoxic substances and Fusarium oxysporum Schl. f. sp. fragariae on the growth and replant disease of strawberry. Front. Agric. China 3: 34-39 